\title{
CONFERINȚA NAȚIONALĂ DE PSIHOLOGIE INDUSTRIALĂ ŞI ORGANIZAȚIONALĂ

\author{
Ediția a VIII-a \\ 10-13 Aprilie 2008, Cluj Napoca
}

\begin{abstract}
Asociația de Psihologie Industrială şi Organizațională (APIO), în colaborare cu Facultatea de Psihologie şi Ştiințe ale Educației, Catedra de Psihologie, organizează în perioada 10 -13 aprilie 2008, la Cluj Napoca, Ediția a VIII-a a Conferinței Naționale de Psihologie Industrială şi Organizațională.
\end{abstract}

Secțiunile conferinței sunt următoarele:

- Managementul Resurselor Umane

- Cultură, Schimbare şi Dezvoltare Organizațională

- Ergonomie Cognitivă

- Psihologie Militară

- Psihologia Reclamei şi Consumatorului

- $\quad$ Emoții în Organizații

În afara acestor sesiuni de lucrări, conferința va include o zi de prelegeri susținute de nume mari în psihologia internațională.

O parte dintre invitații noştri sunt:

- $\quad$ Cary Cooper, Lancaster University Management School, UK

- Ivan Robertson, Leeds University Bussiness School \& Manchester Business School, UK

- Peter van der Berg, Tilburg University, Olanda

- Remi Kouabenan, Université Pierre Mendès, Grenoble, France

- Thomas Oakland, University of Florida

Aceştia vor susține prelegeri pe teme precum stresul ocupațional, analiza riscurilor şi accidenteor ocupaționale, ergonomie cognitivă şi utilizarea testelor psihologice.

Conferința va mai include, de asemenea, o secțiune de workshopuri, cu durată de 4-8 ore la care vă veți putea înscrie în limita locurilor disponibile. Tematica workshopurilor va fi anunțată în curând pe site-ul APIO, www.apio.ro, pe care vă invităm să-I accesați pentru a obține mai multe detalii despre conferință, şi alte evenimente organizate de asociația noastră.

Participarea la conferință precum şi la workshopurile din cadrul acesteia va fi crediată de către Colegiul Psihologilor din România.

Vă aşteptăm cu drag! 